\title{
Islamic Civilization: Its Significance in al-Faruqi's Islamization of Knowledge ${ }^{1}$
}

\author{
WAN SABRI*, W. Y., ZURIATI, M.R., TASNIM, A.R. \& AHMAD, N.A.2
}

\begin{abstract}
This paper discusses the significance attempt of al-Faruqi in making Islamic civilization a mandatory course in his Islamization of Knowledge project. In any attempt of Islamization of Knowledge, the students of Islamization should be comprehensively mastered Islamic Civilization. Al-Faruqi systematically developed four required components in civilizational study that were critical for Islamization project, i.e., to give the Muslim student knowledge of the first principles of Islam as essence of Islamic civilization in the first year; the historical achievements of Islamic civilization in the second year; how Islamic civilization compares and contrasts with other civilizations in essence and manifestation, in the third year, and; how Islamic civilization is the only viable option in dealing with the fundamental problems of Muslims and non-Muslims in the contemporary world, in the fourth year. The significance ideal projected by this comprehensive stages as characterized by al-Faruqi were crucial for student to understand the secular worldview that bring the collapse of civilization in the past and not to repeat this catastrophic consequence in contemporary civilization of the Ummah.
\end{abstract}

Keywords: civilization, al-Faruqi, Islamic Civilization, Islamization of Knowledge

This article provides a brief analysis of the ideas of civilization as propounded by Ismail Raji alFaruqi (1921-1986) and its significance in his Islamization of Knowledge's (IOK) project. In realizing the ideal of civilization, he has outlined the tawhidic principle that governed its construction, as clearly illustrated in his massive work The Cultural Atlas of Islam: "In any integral civilization, and certainly in Islam, the constitutive elements, whether material, structural, or relational, are all bound by one supreme principle. In Islamic civilization, this supreme principle is tawhid. It is the ultimate measuring rod of the Muslim, his guide and criterion in his encounter with other religions and civilizations, with new facts or situations. What accords with it is accepted and integrated. What does not is rejected and condemned" (al-Faruqi 1986). This scheme was realized by al-Faruqi in his endeavor to develop integrated discipline and reforming Muslim education and accomplished Islamic vision in the construction of its syllabus. His aspiration was to produce students that have expertise and comprehensive understanding of Islamic culture and civilization while also strongly grounded in their concentrated course and discipline.

\footnotetext{
1 This article had been presented at $2^{\text {nd }}$ World Conference on Islamic Thought \& Civilization, held by Kolej Universiti Islam Sultan Azlan Shah at Casuarina Hotel @ Meru, Ipoh, Perak, on 18-19 August 2014.

2 Wan Sabri Wan Yusof*(Corresponding author), Ph.D., Professor and Deputy Rector, Kolej Universiti Islam Sultan Azlan Shah, Bukit Chandan, 33000 BANDAR DIRAJA KUALA KANGSAR, Perak, Malaysia, email: wansabri@kuisas.edu.my; Zuriati Mohd Rashid, M.A., Lecturer, Centre for Language Studies and Generic Development, Universiti Malaysia Kelantan, Kampus Jeli, 17600 JELI, Kelantan, Malaysia, email: zuriati.mr@umk.edu.my; Tasnim Abdul Rahman, Lecturer, Faculty of Islamic Contemporary Studies, Universiti Sultan Zainal Abidin, Kampus Gong Badak, 21300 KUALA TERENGGANU, Terengganu, Malaysia, email: tasnimrahman@unisza.edu.my; Ahmad Nabil Amir, Ph.D., Islamic Renaissance Front, Pavilion KL, 168 Jalan Bukit Bintang, 55100 KUALA LUMPUR, Malaysia, email: nabiller2002@gmail.com.
} 
This was undertake in IIUM in general studies courses (UNGS) that outlined the required courses for undergraduates based on Faruqi's workplan, comprising the subjects of Islamic Worldview; Islam, Knowledge and Civilization; and Ethics and Fiqh for Everyday Life. It emphasized on critical aspects of Islamic science and civilization that manifested its comprehensive worldview and fundamental construct. The syllabus reflected the profound aspiration to realize IIUM's significant aim for integration and relevantization of discipline, that constitute crucial element in the IOK project.

The discipline was crafted based on the conceptual framework and paradigm of tawhid and its worldview as espoused by al-Faruqi, which emphasized on four required components in comprehensive stages of study for student to master the discipline. The course strived to highlight the historical achievement of Islamic civilization, and how it compare and contrast with other civilization in essence and manifestation, and its critical role in dealing with fundamental problem of Muslims and non-Muslims in contemporary world. It reflected the universal understanding of Islamic and secular worldview and its intrinsic paradigm, and the crucial aspiration for the reconstruction of Islamic culture and civilization grounded on the essence of unity, rationalism, and tolerance, as strategic based in realizing the planning of IOK. This paper will briefly analyze this idea and its significance in al-Faruqi's worldview as important and crucial part of the IOK project.

\section{Methodology}

This study is fundamentally based on library research. It undertakes extensive study on the works of al-Faruqi that presented his ideas of Islamization of Knowledge (IOK) and its methodological framework, with principle focus on his effort to articulate the essence of Islamic civilization. It will employ the analytical and descriptive method to analyze the data. Some conclusive information was also gathered from interviews and surveys. The data were reviewed and investigated in three stages; general, explorative, and focus study. This constitutes comprehensive material in an attempt to summarize the finding and conclude the result.

\section{The Initiative to Establish the Discipline of Islamic Civilization in IIUM}

This paper highlighted the important initiative of al-Faruqi in developing the discipline of religion and civilization as an integral part of IOK project. It discusses his decisive role in establishing the course of Islamic civilization in IIUM and in defining its fundamental approach and framework. The course emphasize on the essence of Islamic civilization and stresses on its important ideal and manifestation and the universal worldview it projected, as discovered by Ibrahim Zein (2011): "Actually, the establishment of IIUM and the religious study curriculum implemented at IIUM is a development of Faruqi's earlier vision regarding the teaching of Islam as a civilization and worldview, which he had envisioned and hoped to apply to the academic program at the Central Institute of Islamic Research, Karachi, Pakistan during his professorship there in 1960s, but which was not realized". This phenomenal impact was also emphasized by Mona Abaza (2002) in her important work that discusses contemporary discourse on Islam and knowledge in Malaysia and Egypt: "Al-Faruqi was a key figure in creating the International Islamic University in Kuala Lumpur and that in Islamabad. The International Islamic University in Kuala Lumpur established a Department of Revealed Knowledge, which pursues a programme of Islamization of knowledge".

Al-Faruqi's determination and constant effort to introduce the discipline of religion had critically led to the establishment of the Department of Religion in Temple University in the United States. This initiative was unprecedented and 'was a rare exception' (Ibrahim Zein 2011) that has wide implication and monumental impact in the West and intensely followed by a number of institutions in the United States. Initially, the idea was developed since his time in 
Pakistan (at the Central Institute of Islamic Research, Karachi), to establish the religious course from universal perspective and standpoint, which did not materialized. It has also been envisioned earlier in Chicago Islamic College, and in the postgraduate program of Islamic studies in the International Institute of Islamic Thought (IIIT) in North America which has failed, and then, 'the only hope was embodied in this new institution of higher learning (IIUM) established in a country in which al Faruqi had a great trust in its political leadership'. The project was embarked by al-Faruqi by formulating a concept paper that outline the structural planning for the establishment of Islamic University in Malaysia and developed the critical Islamic methodology, which principally rooted on an integrated philosophy of revealed and acquired knowledge. His proposal was realized with the establishment of IIUM in 1983 by the Malaysian government that aspired to implement his profound ideal and philosophy. The IOK project was then comprehensively pursued and 'quite obviously, al Faruqi saw in the establishment of the IIUM a great opportunity for implementing his ideas on Islamic education' (Ibrahim Zein 2011). His dictate was to making Islamic civilization a mandatory course, which should seek to give the Muslim student knowledge of the first principles of Islam as essence of Islamic civilization in the first year; of the historical achievements of Islamic civilization in the second year; how Islamic civilization compares and contrasts with other civilizations in essence and manifestation, in the third year; and of how Islamic civilization is the only viable option in dealing with the fundamental problems of Muslims and non-Muslims in the contemporary world, in the fourth year (al-Faruqi 1982)

Since the establishment of the Kulliyyah of Islamic Revealed Knowledge and Human Sciences (KIRKHS) in 1990, the teaching of Islam and other religion had been introduced and 'has been largely influenced by the works of Ismail R. al-Faruqi - especially Christian Ethics, Islamization of Knowledge, and Cultural Atlas of Islam'. In fact: "the establishment of IIUM and the religious study curriculum implemented at IIUM is a development of Faruqi's earlier vision regarding the teaching of Islam as a civilization and worldview". Using his theory and ideas of religion as a 'life-fact', and his challenged to 'the discipline of the history of religion from within', and his usage of the canons of universal rationality to argue for both Islamic and secular humanism, it has 'encouraged Muslim scholars to engage others in a meaningful inter-religious dialogue, and not to be inhibited by the secular humanist restrictive agenda' (Ibrahim Zein 2011).

\section{Four Stages of Civilizational Study According to al-Faruqi}

In his endeavor to Islamize and integrate the discipline of revealed and human knowledge, alFaruqi had strived to project its framework based on the worldview of tawhid that governed its fundamental structure. This has been profoundly developed in the discipline of Islamic civilization that essentially grounded in the framework and method of IOK. Its content and syllabus was systematically crafted based on the principle of tawhid and divided in four critical stages. It constituted profound approach in understanding and comparing the essence and manifestation of Islamic and Western civilization and in analyzing its merit and discontent. We will attempt to elaborate this important initiative based on the philosophical ideal of tawhid and the worldview projected by al-Faruqi, and its significant impact in IIUM.

Year One: To give the Muslim student knowledge of the first principles of Islam as essence of Islamic civilization in the first year. The need to emphasize on the principle of tawhid is crucial for student to understand its constitutive element and ideal, that stood out as the first principle and essence of Islam, as advocated by al-Faruqi: "Tawhid, or the doctrine of absolute unity, transcendence, and ultimacy of God, implies that only He is worthy of worship, of service. The obedient person lives his life under this principle. He seeks to have all his acts to conform to the pattern, to actualize the divine purpose. His life must therefore show the unity of his mind and will, the unique object of his service. His life will not be a series of events put together helter skelter, but 
will be related to a single overarching principle, bound by a single frame that integrates them together into a single unity. His life thus has a single style, an integral form in short, Islam". This fundamental ideal and principle form the integral dimension in the formation of Islamic civilization and the realization of its worldview, embedded in its methodological dimension, which emphasized on the principle of unity, rationalism, and tolerance and the alternative paradigm of tawhid, as manifested in his argument: "the methodological dimension (of tawhid) includes three principles, namely, unity, rationalism, and tolerance. These determine the form of Islamic civilization, a form that pervades every one of its departments". This principle was further accentuated and reinforced in his exposition on the essence of Islamic civilization: "there can be no doubt that the essence of Islamic civilization is Islam; or that the essence of Islam is tawhid, the act of affirming Allah to be the One, absolute, transcendent Creator, Lord and Master of all that is. These two fundamental premises are self evident. They have never been in doubt by those belonging to this civilization or participating in it" (al-Faruqi 1986). This fundamental ideal has been comprehensively implemented in IIUM through some required courses in UNGS (general studies) for undergraduates. Students were required to take fundamental subjects in Islamic Worldview; Islam, Knowledge and Civilization; and Ethics and Fiqh for Everyday Life. These prerequisite courses were geared to expose students to the fundamental element in Islamic worldview, the concept of tawhid and its implications for life, the challenges of postmodernism and secularism, basic principle of Islamic theology and philosophy, characteristics and fundamental essence of Islam as main components in the syllabus. Its principal references were derived from some major works of al-Faruqi such as Al-Tawhid: Its Implications for Thought and Life, The Cultural Atlas of Islam, Islam and other works that expounded this critical ideas by alAttas, Fazlur Rahman, Al-Qaradawi, A. Berghout, M. Mutahhari, M. Kamal Hassan, 'Abdul Hamid A. Abu Sulayman, Maududi, Syed Qutb, Fathi Osman, S. H. Nasr, etc. Its principle element and structure was grounded on the framework of IOK aimed to Islamize the discipline and to highlight the core ideal of tawhid, which reflected the need to integrate the fundamental idea of God in social, legal and other intrinsic dimension and sphere of life, as illustrated by al-Faruqi: "At the core of religious experience stands God... The name of God, 'Allah', which simply means 'The God', occupies the central position in every Muslim place, every Muslim action, every Muslim thought. The presence of God fills the Muslim's consciousness at all times" (al-Faruqi 1992).

Year Two: Of the Historical Achievements of Islamic Civilization in the Second Year. The significant important to reflect the historical achievements of Islamic civilization was exponentially advocated by al-Faruqi to revitalize Islamic teaching and its intellectual tradition and creativity: "The world ummah of Islam will not rise again or be the ummatun wasatun except through that which is its raison d'etre fourteen centuries ago, its character and destiny through the ages, namely Islam" (al-Faruqi 1982) He strived to advocate intellectual revolution and the reconstruction of Islamic world order and the revival of scientific spirit and its intellectual legacy and heritage, and the renewal of culture and ideas: "We have an extremely important task ahead of us. As social scientists, we have to look back at our training and reshape it in light of the Quran and the Sunnah. This is how our forefathers made their own original contribution to the study of history, law and culture. The West borrowed their heritage and put it in secular mould. Is it asking for too much that we take knowledge and Islamize it?" (quoted in Ilyas Ba-Yunus 1988). The intense need to reclaim the ideal of tajdid, and to revive the classical legacy and achievement of Muslim civilization, and to restore the leading role of the ummah in contemporary world was also projected in IIUM's vision, as encapsulated in the Presidential remark of former IIUM President, Anwar Ibrahim: "The survival of the Muslim civilization will and must be a work of scholarship that is not merely abstract but also informed by and sensitive to the pressing problems and concerns of the world in which we live. Knowledge is the most important resource of the present day global economy. If Muslims do not equip themselves to succeed and thrive in the new economy of knowledge they will fall further behind. If Muslims do not learn how to enter the new economy of knowledge through the conceptual world of Islam they 
consign themselves to a future that is as fractured and problem ridden as has been our recent past" (International Islamic University Malaysia 1998). This aspiration to encourage the thriving of ideas and knowledge was also emphasized by him in his keynote address at the International Seminar on Malik Bennabi. While discussing in great depth the phenomenal influence and profound ideas of Bennabi and his genuine contribution in articulating the ideas of civilization, he presented his principle contributions to prescribe the prerequisite for civilizational renewal (shurut al-nahdah): "He argued that proficiency and efficacy in nurturing ideas is a vital sign of intellectual and cultural development. In elaborating the role of ideas in the development of civilization, he went to the extent of saying that a civilization prospers but by the depth of its guiding ideas". Bennabi's radical aspiration for change was triggered by an inner struggle for reform and collective consciousness for renewal that inspired the proliferation of ideas and reconstruction of thought, as encapsulated in his argument, 'a civilization is the translation of ideas into intellectual capacity and material means to organize one's environment' (Anwar Ibrahim 1991). The need to articulate the idea of civilization and the formidable history of Islam and its significant achievement was crucial for students to appreciate the example of righteous forbearers (salaf al-salih) and their lasting impact in classical tradition and intellectual history of Islam and their important legacy and the high culture that it produce. Understanding Islamic history and culture was essential in realizing the aspiration of tawhid in modern time with the intricacies of life and current demand of science and technology. It underscored the need to revitalize the ideal of tawhid and its universal approach to knowledge, with the complexities of modern life. This reflected the idea to synthesize the classical ideal and tradition of Islam with the dynamic urge of contemporary life and to restore the dynamic foundation of arts, science, and philosophy in medieval Islam.

Year Three: How Islamic Civilization Compares and Contrasts With Other Civilizations In Essence and Manifestation, In The Third Year. By suggesting to compare and contrast Islamic with other civilization, in essence and manifestation, al-Faruqi pointed out the essential worldview and ideology that divide the secular and tawhidic world order. He emphasized on the constitutive element of Islamic civilization and of the 'threateningly dangerous malaise' (alFaruqi 1982) of Muslim learning system, its stagnation and backwardness, and dependency on foreign ideas, and uncritical acceptance of traditional ruling, while also suggested to embrace the difference and appreciate foreign value and ideal and its deep-seated relation and strength, as he categorically maintained: "the civilization of Islam places elements in an orderly structure and governs their existence and relations according to a uniform pattern. In themselves, the elements can be of either native or foreign provenance. Indeed, there is no civilization that has not adopted some elements foreign to it. What is important is that the civilization should digest those elements, that is, it should recast their forms and relations and thus integrate them into its own system...if the civilization has succeeded in transforming them and integrating them into its system, the integrating process becomes its index of vitality, of its dynamism and creativity" (al-Faruqi \& al-Faruqi 1986). This significant ideal has been developed in the UNGS (general studies course) in IIUM as required subjects for undergraduates. These include The Islamic Worldview and Islam, Knowledge and Civilization that presented comparative analysis of Islamic and western perspective of knowledge. It outlined the fundamental ideas and worldview it projected emphasizing on its origin, method and purpose of knowledge. While Islamic perspective of knowledge was founded on holistic purpose, based on tawhidic framework, the western ideal based on reason and speculation, empirical fact and natural sense, rejecting thereby revelation as ultimate source of knowledge. This remind us of the argument of al-Attas of the undue influence and onslaught of secular ideologies and its skepticism leading to confusion of knowledge, as articulated in his work on the concept of Islamic philosophy and education: "Islam does not concede to the dichotomy of the sacred and the profane; the worldview of Islam encompasses both al-dunya and al-akhirah, in which the dunya-aspect must be related in a profound and inseparable way to the akhirah-aspect, and in which the akhirah-aspect has 
ultimate and final significance" (al-Attas 1995). Al-Faruqi had adopted a selective approach to western value. He synthesizes the traditional position of Muslim scholar towards western ideal by accepting its rational and scientific premise into modern Islam. The reform of Muslim education needs to be substantiated with other formidable values and ideas of foreign civilization to contribute to dynamic change and transformation of the ummah that transcend the universal aspiration of humanity and world civilization.

Year Four: Of How Islamic Civilization Is The Only Viable Option In Dealing With the Fundamental Problems of Muslims And Non-Muslims In the Contemporary World, In the Fourth Year. After contemplating on the essence, the historical achievement and the characteristic of Islamic and other civilization, the final stage emphasize on the superior position of Islam as the only viable option in dealing with the fundamental problem of the contemporary world. This conclusive finding emphasized on the supremacy of Islamic civilization that was unsurpassed in its ethical tradition, affirmation of life and rational spirit, and recognition of mankind and confirming the ideal of humanism, as explained in his work: "the humanism of tawhid alone is genuine. It alone respects man as man and creature, without either deification or vilification. It alone defines the worth of man in terms of his virtues, and begins its assessment of him with a positive mark for the innate endowment God has given all men in preparation for their noble task. It alone defines the virtues and ideals of human life in terms of the very contents of natural life, rather than denying them, thus making its humanism life affirmative as well as moral" (al-Faruqi $\&$ al-Faruqi 1986). The current ideologies and secular worldview must be confronted and debunked for it has failed to defend the fundamental ideal of humanity. Its principle ideal and underlying premise are incapable of providing meaning to education and has created confusion in knowledge, as succinctly illustrated by Harry R. Lewis, former Dean of Harvard College in his book Excellence Without a Soul: Does Liberal Education Have a Future?, that examined the fundamental crisis in liberal education that has lost its purpose in inspiring the mind and realizing the meaning of education, and in safeguarding human spirit: "The old ideal of a liberal education lives on in name only. No longer does Harvard teach the things that will free the human mind and spirit". He argued that Harvard has abandoned its mission, to realize the fundamental aspiration and significance meaning and essence in the quest of "what it means to be human", instead the ultimate striving for knowledge has turn into securing economic benefit: "The great universities are respected and certainly prized in America, but the public regards with increasing skepticism the values they represent and their failure sometimes to represent any values at all. As their cost zooms towards \$50,000 per year and their intellectual content becomes more estranged from anything comprehensible to ordinary citizens, they will be regarded as sources of economic security for their graduates but not of intellectual or personal inspiration". In his conclusion, Lewis quote the optimism of former Dean of Students, Archie C. Epps III, to reconstruct the ideal philosophy and aspiration that has loss to be the benchmark of America's flagship university: "Harvard can again inspire its students to develop a philosophy of life that brings dignity and honor to human affairs if it signals those values in everything it does" (Lewis 2007). Anthony T. Kronman in his groundbreaking analysis of the same crisis, in his book Education's End: Why Our Colleges and Universities Have Given Up on the Meaning of Life has emphasize the need to revitalize the fundamental meaning of knowledge and humanity in liberal education that has lost its purpose in this educational barbarism.

This was also reflected by Mohd. Kamal Hassan in his forward to the influential book Reclaiming the Conversation: Islamic Intellectual Tradition in the Malay Archipelago that analyze the dynamic thought and contributions of eleven Muslim scholars and intellectuals in Malay archipelago to Islamic education, It has been lamented: 'where is the knowledge that is lost in information and the wisdom lost in knowledge?' Worst still, education has been reduced to the 'dehumanisation' of human beings where the souls and spirits are ignored. Instead of education that refines the individual's soul to something purer, sublime and illuminated with sacred knowledge, the present education has polluted or tainted the innocent souls with baser desires 
to the extent that human beings begin to see others as a means and not as ends in themselves. Man has also began to lose his human dignity" (Rosnani Hashim 2010). The modern secular worldview has dramatically failed to safeguard the principle aspiration of human ideal, resulted in the decline of its fundamental value and spirit, as lamented by T. S. Eliot (1888-1965): "Where is the life we have lost in living? Where is the wisdom we have lost in knowledge? Where is the knowledge we have lost in information?" He presaged the uncertainties in this information age, lamented on the lost of purpose in knowledge that has been confounded with the flood of information, driving mankind into unprecedented decline and collapse of moral integrity in consequence of crass technological advance and materialistic outlook it projected. This resonate the educational philosophy outlined by Syed Muhammad Naquib al-Attas that maintained that the aim of Islamic education is to produce $a d a b$, the wholesome and cultured, comprehensive and balanced, and well-mannered person, and in perfecting moral vision and instilling holistic worldviews and integrating the refined quality and wisdom of rational man, as opposed to the concept of ta lim in western construct. Which implied that the secular worldview and its method had failed to answer the crisis of modern knowledge and its current malaise.

In the field of Islamic finance, its comprehensive and pragmatic solution to global financial crisis has been adopted by the World Bank as viable option for the current malaise in international market and industry. The emerging shariah-based market has attracted wide sector of economy to partake in implementing the Islamic system as the leading financial option that dominated the global economy. This has been confirmed by Volker Nienhaus, Professor of Economics and former President of the University of Marburg, Germany, in his speech in Doha, asserting its vitality as viable option to resist the financial breakdown and provide alternative solution to conventional economy: "Islamic banking has come a long way and become a viable option for everybody, including non-Muslims. A Shariah-compliant banking scheme is a better financial option as it has no excessive risks and does not engage in questionable business" (Nawal Hussein 2013; Varghese 2013). This is the fundamental objective of al-Faruqi's approach, to Islamize the discipline and reclaim the profound aspiration of tawhid. The important of Islamic method is reflected in the four stages of civilizational study as projected in his work plan and integrated as fundamental course in IIUM. The description prescribed by al-Faruqi in each years of study suited the need for students to comprehend the idea of civilization and developed expertise and mastery of the discipline. The course strived to realize the ideal of Khayr Ummah (the best nation), that uphold the principle of justice, command what is right and forbidding wrong (amr bi al-ma 'ruf, wa nahy 'an al-munkar). This inevitably relates to Quranic injunction in 2:143 of 'civilizational witnessing' which implies 'divine injunction upon Muslim to be the example and standard for human civilization as a manifestation of being rahmah li al-'alamin (mercy to the universe)' [21:107] (Rosnani Hashim 2010). And this was constructed and founded upon the pillars of tawhid and knowledge as viable option for humanity as propounded by al-Faruqi.

From this brief outline, it is clearly manifested that knowledge is a basic and fundamental part of civilization that inspired the mushrooming of ideas which thrive in classical Islam in its most creative period. It has been an integral part of the movement of IOK led by alFaruqi which aspired to revitalize the Islamic intellectual and religious tradition and reclaim the dynamic and leading role of the ummah in the modern world. IIUM has making great stride to realize this significant aspiration by imposing certain prerequisite courses as mandatory subjects for undergraduates, such as The Islamic Worldview; Islam, Knowledge and Civilization; and Ethics and Fiqh for Everyday Life (in general studies course). The initiative was also undertake by the Department of History and Civilization of the Kulliyyah of Islamic Revealed Knowledge \& Heritage and Human Sciences (KIRKHS) offering the subjects of The Rise and Fall of Ancient Civilization; Islamic History and Civilization; Central Asian History; and The Coming of Islam to South and Southeast Asia. The Kulliyyah has creatively synthesized the ideas and scheme projected by al-Faruqi by establishing this discipline gearing students to critically 
master the essence and manifestation of Islamic civilization as crucial part of IOK's project. AlFaruqi emphasized on substantial reform to reconstruct the worldview based on the epistemology of tawhid and to reclaim the scientific achievement and intellectual tradition of Islamic civilization and to reinvigorate the spirit of ijtihad. This fundamental aspiration was crucial to revitalize contemporary ummah and to inspire the flowering of ideas, art and science in modern time for rigorous civilizational renewal of the ummah.

\section{Acknowledgements}

This research is funded by Research Acculturation Grant Scheme (RAGS) of Ministry of Education and Universiti Sultan Zainal Abidin (UniSZA).

\section{References}

Ahmad, Baharudin. 2009. The Meaning of Civilization as perceived by Malays. In Islam Hadhari: Bridging Tradition and Modernity. Kuala Lumpur: International Institute of Islamic Thought and Civilization.

Anwar, Ibrahim. 1991. Keynote Address. International Seminar on Malek Bennabi. 1-4 September, University of Malaya Institute of Advanced Studies, Kuala Lumpur.

Fiorina, Carly. 2002. Technology, Business and Our Way of Life: What's Next. Hewlett Packard.Online.

http://www.hp.com/hpinfo/execteam/speechess/fiorina/minnesota01. html [12 April 2014].

Gilani, Sayyid Muhammad Yunus \& Islam, Tazul. 2013. Nation's rise and fall: A Search for dynamics from Quranic perspective. In $3^{\text {rd }}$ International Seminar of Wahyu Asas Tamadun 2013 (SWAT 2013), 20-21, USIM, Nilai, Negeri Sembilan.

Ibrahim Mohamed Zein. 2011. Religion as a 'Life-Fact': Al Faruqi's impact on the International Islamic University Malaysia. The American Journal of Islamic Social Sciences 28(3): 3557.

Ilyas Ba-Yunus. 1988. Al-Faruqi and Beyond: Future directions in Islamization of knowledge. American Journal of Islamic Social Sciences 5(1): 13-28.

International Islamic University Malaysia. 1998. Undergraduate Prospectus 1998-99. Petaling Jaya: International Islamic University Press,.

Ismail al-Faruqi. 1982. Islam as culture and civilization. In Salem Azzam (ed.). Islam and Contemporary Society. London: Longman.

1982. Islamization of Knowledge: The General principles and the work-plan. In Knowledge for what? Proceedings of the Seminar of Islamization of Knowledge. Institute of Education, Islamabad.

1982. Nahwa Jami'ah Islamiyah. Al-Muslim al-Mu'asir 9(33): 47-56.

1992. Tawhid: Its Implications for thought and life. Wyncote: International Institute of Islamic Thought (IIIT).

Ismail al-Faruqi \& Lois Lamya al-Faruqi. 1986. The Cultural Atlas of Islam. New York: Free Press.

Lewis, Harry. 2007. Excellence without A Soul: Does Liberal Education have a future? New York: Public Affairs.

Miriam Abdul Halim. 2007. A Study of the thought of Ismail Faruqi on science, Islam and modernity. (Unpublished M. Sc. Dissertation). Jabatan Pengajian Sains \& Teknologi, Fakulti Sains, Universiti Malaya.

Mona Abaza. 2002. Debates on Islam and knowledge in Malaysia and Egypt: Shifting worlds. London: Routledge.

Muhammad Asad. 1980. The Message of the Quran. Gibraltar: Dar Al-Andalus. 
Nawal Hussein Abbas El-Hussein. 2013. Islamic Finance: Is it a viable option to restrain financial crisis? Interdisciplinary Journal of Contemporary Research in Business 5(4): 576-588.

Rosnani Hashim (ed.). 2010. Reclaiming the conversation: Islamic intellectual tradition in the Malay Archipelago. Kuala Lumpur: The Other Press.

Syed Muhammad Naquib al-Attas. 1995. Prolegomena to the Metaphysics of Islam: An Exposition of the fundamental elements of the worldview of Islam. Kuala Lumpur: International Institute of Islamic Thought and Civilization.

Varghese, Joseph. 2013. Islamic Banking 'Viable option for non-Muslims too'. Gulf-Times, Online. http://www.gulf-times.com/qatar/178/details/344919/-islamic-banking-'viableoption-for-non--muslims-too. 